\title{
The Efficiency of Administrative CPD Courses towards School Managers
}

\author{
Ahmet Bozak ${ }^{1}$, Mümtaz Karadağ ${ }^{2} \&$ Yavuz Bolat ${ }^{3}$ \\ ${ }^{1}$ Mustafa Kemal University, Education Faculty, Educational Administration and Supervision, Hatay, Turkey. \\ ${ }^{2}$ The Ministry of National Education of Turkey, Ministerial Educational Inspector, Turkey. \\ ${ }^{3}$ Mustafa Kemal University, Education Faculty, Curriculum and Instruction, Hatay, Turkey. \\ Correspondence: Ahmet Bozak, Mustafa Kemal University, Educational Administration and Supervision, Turkey
}

Received: March 21, 2018

Accepted: April 5, 2018

Online Published: April 11, 2018

doi:10.5430/ijhe.v7n2p234

URL: https://doi.org/10.5430/ijhe.v7n2p234

\begin{abstract}
The aim of this study is to define the points of view of the schools directors on administratorship CPD training course organized by local educational directorates. A mixed model was used in this study and related data was evaluated both at quantitative and qualitative dimensions. The sample group was formed by 174 participants among 567 school directors who participated to the administratorship CPD training course organized by Şanliurfa Local Educational Directorate in Bozova, Haliliye, Siverek and Viranşehir districts in educational year of 2015 and 2016, and study group was formed by 149 school directors who participated the CPD training course in the same educational districts. Data was collected via a survey in quantitative dimension and by phenomenological interviewing technic in qualitative dimension. In the study, it was concluded that CPD course led the participants acquire new knowledge and skills, and have new perspective and understanding related to school management, the content of training course and qualification of the instructors were efficient enough according to the participant school managers, the CPD course was sufficient in terms of educational tools and equipment, school managers pay more attention to self-learning and find the CPD course sufficient enough in terms of self-learning opportunities, participants are concerned about the teaching methodology of the training course and they demand to have teaching methods which will depend on practical and operative activities rather than theoretical and academic information, the participants were not satisfied with the facilities supplied by the CPD organization, the timing of the CPD course was not welcomed and many participants stated their negative concern about the timing of the CPD course as it was held within educational year and as they had to manage their school simultaneously.
\end{abstract}

Keywords: CPD, school managers, administrative training, efficiency

\section{Introduction}

Since the rapid global changing in social and economic fields, the concept of personal management has been replaced by the concept of human resource management and this leads to demands new prospects and qualifications for the employees, CPD training plays an important role in such a process for responding those qualifications of employees. (Taymaz, Sunay \& Aytaç, 1997).

The improvement of personal qualifications has an important and key role in the process of a society's development. In order to improve individuals' own qualifications, employees should be harmonized with the society they live in, and should acquire the knowledge, skills, attitudes and behaviors that demand to endeavor in the professional development fields (Gültekin \& Çubukçu, 2008). A person should be able to maintain his knowledge and qualification within his job in order that he adapt himself to changing and complete the knowledge and qualification that he got via his education (Karaman, 1983).

CPD training can be defined as a type of on-the-job training that is given for employees' gaining required knowledge, skills and attitudes for their jobs. (Taymaz, 1997; Aytaç, 2017). In the process of CPD training, an employee improves himself with his own efforts and also with organizational guiding efforts since the first day of beginning of his work to end of his work in the organization (Pehlivan, 1997).

CPD training, as a part of lifelong learning education, is regarded to be an important organizational process which comprises all the professional involvement from the beginning of profession to the end (Sabuncuoğlu, 2005; Kulaz, 2013). CPD training is generally implemented in order to get organizational orientation of new employees, have the employees learn the organizational rules and policies, have the employees gain the necessary qualifications for the job by motivating and orienting them towards changing in the field of his/her own profession (Atakl1, 1992; Öztürk \& Sancak, 2007). 
CPD training activities are thought to make so many contributions to an organization both at individual and also at organizational levels. (Taymaz, 1997). In such a process, individuals are likely to make contribution to fulfillment of organizational targets by gaining the necessary qualifications for the job. As in the other organizations, school managers' having CPD training, can be regarded as professional development opportunities as well as it improves the organizational effectiveness and productiveness. Although CPD training activities can make a lot of contributions to an organization, it is also considered to be a kind of activity that costs high expenses for the organizations (Özcan \& Bakioğlu, 2010).

A number of CPD training activities have been organized by local provincial educational directorates of Turkey towards newly started school directors in order that they could be successful at their new job, have innovative perspectives, follow the changings, and have personal and professional developments in the field of administration. In educational year of 2015 and 2016, an administratorship CPD training course was organized by Şanliurfa Local Educational Directorate and 567 newly started school directors joined this training organization. The training course lasted 3 weeks and school directors had 90 hours of training about the topics such as educational leadership, developing vision and strategy, school culture, organizational behavior, project management, school management, professional and administrative ethic, quality management at education, time management, protocol rules, conflict and stress management, performance management at education, school environment relations, team work, problem solving technics, running a educational institution, ICT, managing modular personal information systems of Turkish Ministry of Education, fiscal management, fiscal laws and regulations, school hostels management, inspection and inquiry, consulting and guiding, management of special education, rules of official correspondence. However, the efficiency of these CPD organizations towards school managers has not been studied in Turkey yet. The aim of this study is to define the views of schools directors on administratorship CPD training courses organized by local educational directorates. With this study it is expected to make contribution to development and reconfiguration of CPD training by evaluating the views of the participants towards administrative training courses.

\section{Method}

\subsection{Research Context}

The aim of this study is to define the points of view of the schools directors on administratorship CPD training course organized by local educational directorates. A mixed model was used in this study and related data was evaluated both at quantitative and qualitative dimensions. In a mixed study, different study technics are used together in order to have multiple data, in this process, both quantitative and qualitative models are used to disclose the problem of the study (Johnson \& Turner, 2003; Creswell, 2006).

\subsection{Participants}

The sample group was formed by 174 participants among 567 school directors who participated to the administratorship CPD training course organized by Şanlıurfa Local Educational Directorate in Bozova, Haliliye, Siverek and Viranşehir districts in educational year of 2015 and 2016, and study group was formed by 149 school directors who participated the CPD training course in the same educational districts.

\subsection{Measures}

Data was collected via a survey in quantitative dimension and by phenomenological interviewing technic in qualitative dimension, in this technic questions are asked in a systematical order to lessen the subjectiveness of the participants and also, it is regarded to be a technic by means of which a researcher can evaluate the qualitative data relatively easy (Punch, 2005; Yıldırım \& Şimşek, 2013; Karasar, 2017).

The data in quantitative dimension was collected via a questionnaire which consists of 30 items and in quantitative dimension two standardized open-ended interview questions. In the quantitative research process, the data items mainly focus on the participant views on effectiveness, usefulness and general evaluation of the CPD training course. Survey is regarded to be a means of quantitative data collection tool mainly used for the purpose of researching larger samples as well as to be an economical and time saving method (Büyüköztürk, Akgün, Demirel, Çakmak \& Karadeniz, 2018). The quantitative part of the survey is a standardized questionnaire which has already being used for evaluating the training courses by CPD training department of Turkish Ministry of Education.

As a qualitative data collection tool in the study, two phenomenological open ended interviewing questions were developed for the profound understandings of school managers' views and thoughts about the CPD training course they had. After literature being reviewed about theoretical background of CPD training, an interview form, consisting of 2 open ended questions the aims of which is to disclose the views of managers in a deeper and more profound way, was developed by the researchers. In the phenomenological interviewing form, these questions stating "What are the topics 
that are going to make the best contributions to your personal development in this training course you had?" and "What are your advices for this CPD training course's being more effective and useful?" were asked to school managers.

The questionnaire used in the study has three chapters; first chapter is formed by 2 items of demographic characteristics about school types and seniority. The second chapter is formed by quantitative items, in order to evaluate the views of school managers about CPD training, 30 items were asked in quantitative dimension. The survey items of the Likert type of 5 were organized and scored from the lowest score 1 up to the highest score 5 , according to this scale agreement level of the participants were scored as strongly disagree (1), disagree (2), neutral (3), agree (4), strongly agree (5). In the third chapter of questionnaire, in the qualitative part, school managers were asked to write their points of view via phenomenological open ended questions by means of which is aimed to have school managers express their views and thoughts in a more detailed and profound way.

The validity of the phenomenological interview was formed by two academicians from educational management field as well as two educational inspectors. The questions were finally formed via by group focus meeting by the researchers and educational inspectors. The views of school managers gathered by these two open ended questions were analyzed via descriptive analysis method, the frequency (f) and percentage (\%) values of school managers' views on CPD training are indicated in tables as well as quoted via direct citations, in order to find out the similar views and statements of the participants about CPD training was gathered into groups, some of the important views of participants were also quoted via direct citations as well as by frequency distribution. Descriptive analysis is made within four steps, first, a conceptual shame is formed by the researcher to define the theme of the analysis, second, the researcher read the datas and organize them according to defined conceptual shame, it is important to put the data in a meaningful order in this step, third, the researcher define the data which s/he gathered in a meaningful order as well as s/he quotes the important views, for the fourth and last step, researcher explains the data s/he has defined, relates the data with the other points and evaluate them in related dimensions of search, s/he also explain and compare the findings in cause effect relationships (Yildirım and Şimşek, 2003). In accordance with these steps, qualitative data which is formed by comments, clarifications and suggestions were listed within general themes and interpreted in tables. As a principle of confidence in the survey, each school manager was coded by abbreviations beginning from M-1 to M-174.

\subsection{Procedure}

In educational year of 2015 and 2016, an administratorship CPD training course was organized by Şanlıurfa Local Educational Directorate and 567 newly started school directors joined this training organization. The training course lasted 3 weeks and school directors had 90 hours of training about the topics previously mentioned in introduction section of the study. The survey was answered by school managers at the end of the CPD training course, 174 volunteer participants among 567 school managers joined the first 2 chapters in quantitative dimension while 149 volunteer participants answered the phenomenological open ended questions of qualitative dimension in the last chapter.

\section{Findings}

In this chapter, the research quantitative and qualitative findings are discussed under two headings. Accordingly, the results of quantitative data items were represented first, then the result of qualitative phenomenological open ended questions were interpreted.

3.1 The Quantitative Findings Related to School Managers' Views on Administrative CPD Training Course Organized by Local Educational Directorates.

In this heading, 30 items in the first chapter of questionnaire and the frequency (f) and percentage (\%) values according to school managers' views on CPD training are discussed. The demographic data related to participant is shown in Table 1. 
Table 1. Demographic data of participants indicating school type and seniority

\begin{tabular}{llll}
\hline Demographic data & Participants & $(\%)$ \\
\hline \multirow{5}{*}{ School type } & Pre-school & 12 & 6,9 \\
& Primary & 67 & 38,5 \\
& Secondary & 24 & 13,8 \\
& Primary-secondary & 51 & 29,3 \\
& (united) & 20 & 11,5 \\
& High School & 174 & 100,0 \\
\hline \multirow{5}{*}{ Seniority } & Total & 115 & 66,1 \\
& 1-10 years & 48 & 27,6 \\
& 11-20 years & 11 & 6,3 \\
& 21 years and over & 174 & $\% 100$ \\
\hline
\end{tabular}

As it is shown in table 1, 12 participants $(6,9 \%)$ work in pre-schools, 67 participants $(38,5 \%)$ work in primary schools, 24 participants $(13,8 \%)$ work in secondary schools, 51 participant $(29,3 \%)$ work in united primary-secondary schools, and 20 participants $(11,5 \%)$ work in high schools as school managers.

When seniority of participant are analyzed, $66,1 \%$ of the participants have seniority of $1-10$ years, $27,6 \%$ of the participants have seniority of 11-20 years, and 6,3\% of the participants have seniority of 20 years and over.

In the analysis of the views of school managers about effectiveness and usefulness of CPD training course they had, frequency and percentage values of the school managers was examined shown in table 2 below:

3.1.1 The Mean, Standard Deviation, Frequency and Percentage Related to Administrative CPD Evaluation Survey.

Table 2. Mean standard deviation frequency and percentage values of the school managers on CPD evaluation survey items.

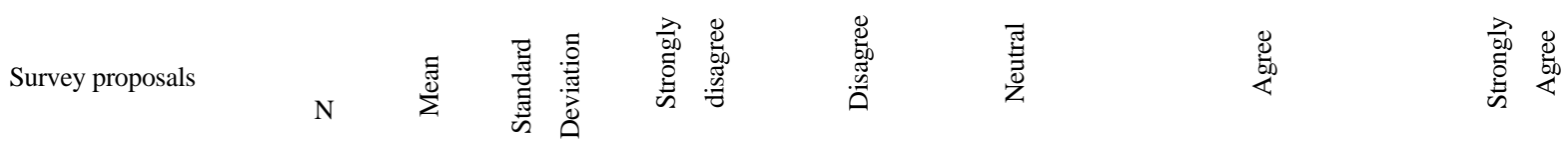

\begin{tabular}{|c|c|c|c|c|c|c|c|c|c|c|c|c|c|}
\hline & & & & $\mathrm{f}$ & $\%$ & $\mathrm{f}$ & $\%$ & $\mathrm{f}$ & $\%$ & $\mathrm{f}$ & $\%$ & $\mathrm{f}$ & $\%$ \\
\hline $\begin{array}{l}\text { 1. The content of this CPD } \\
\text { training course taught me } \\
\text { new topics. }\end{array}$ & 174 & 4,35 &, 80 & 5 & 2.9 & 1 & 0,6 & 3 & 1,7 & 84 & 48,3 & 81 & 46,6 \\
\hline $\begin{array}{l}\text { 2. The content of this CPD } \\
\text { training course brought me } \\
\text { in new skills. }\end{array}$ & 173 & 4,17 &, 88 & 6 & 3.4 & 4 & 2,3 & 6 & 3,4 & 94 & 54,0 & 63 & 36,2 \\
\hline $\begin{array}{l}\text { 3. The content of this CPD } \\
\text { training course brought me } \\
\text { in new perspective and } \\
\text { understanding. }\end{array}$ & 173 & 4,22 &, 84 & 5 & 2,9 & 3 & 1,7 & 7 & 4,0 & 91 & 52,3 & 67 & 38,5 \\
\hline $\begin{array}{l}\text { 4. The training course that I } \\
\text { have joined is likely to } \\
\text { improve my professional } \\
\text { knowledge, qualifications } \\
\text { and skills. }\end{array}$ & 174 & 4,14 &, 72 & 3 & 1,7 & 3 & 1,7 & 8 & 4,6 & 111 & 63,8 & 49 & 28,2 \\
\hline $\begin{array}{l}\text { 5. The training course had } \\
\text { me gain the necessary } \\
\text { knowledge }\end{array}$ & 172 & 4,08 &, 74 & 2 & 1,1 & 5 & 2,9 & 14 & 8,0 & 106 & 60,9 & 45 & 25,9 \\
\hline
\end{tabular}


qualifications which I can apply to my managerial life

6. The new knowledge and qualifications in the content of training course is

7. The duration of the training course was enough to get the new knowledge in

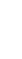
$169 \quad 3,28$ its content

8. The duration of the training course was enough to get the new perspective and understanding in its 170

content

9. The time was effectively used in the training course.

10. Instructors had enough knowledge and skills related to content of the course.

11. Instructors made enough explanation about the topics.

12. Instructors gave enough samples related to topics.

13. The topics at the training course were effectively presented.

14. There was enough instructor-participant interaction at the course.

15. There was enough participants-participants interaction at the course.

16. There was an effective communication $\begin{array}{lllllllll}169 & 4,10 & , 77 & 2 & 1,1 & 5 & 2,9 & 15 & 8,6\end{array}$

$\begin{array}{lllllllllllll}173 & 4,46 & , 73 & 2 & 1,1 & 2 & 1,1 & 7 & 4,0 & 65 & 37,4 & 97 & 55,7\end{array}$

$\begin{array}{lllllllllllll}174 & 4,36 & 68 & 1 & 0,6 & 3 & 1,7 & 6 & 3,4 & 86 & 49,4 & 78,8\end{array}$

$\begin{array}{lllllllllllll}174 & 4,36 & , 77 & 1 & 0,6 & 5 & 2,9 & 11 & 6,3 & 70 & 40,2 & 87 & 50,0\end{array}$

$\begin{array}{lllllllllllll}174 & 4,17 & , 80 & 4 & 2,3 & 3 & 1,7 & 10 & 5,7 & 99 & 56,9 & 58 & 33,3\end{array}$

$\begin{array}{lllllllllllll}173 & 4,16 & , 84 & 4 & 2,3 & 5 & 2,9 & 11 & 6,3 & 92 & 52,9 & 61 & 35,1\end{array}$

$\begin{array}{llllllllllll}174 & 4,18 & , 77 & 2 & 1,1 & 6 & 3,4 & 9 & 5,2 & 98 & 56,3 & 59\end{array}$
environment at the course.

17. Participants did adequately benefit from the opportunities of conversation.

18. The organization of the training course was satisfactory.

19. The course has clear training objectives which are observable and evaluable.

20. The content of the training course is prepared accordance with the 17

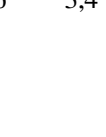


21. The training course was not forth attending, it was waste of time.

22. It was difficult for me to adopt the new ideas and applications within the content of training course as they were contrary to my previous learning and attitude's.

23. Suitable educational tools and equipment were used during the training course.

24. The new knowledge I got during the training course will increase the success at my profession.

25. Instructors dominated, single tracked presentation was used in the training course.

26. In the training course, a knowledge learning procedure was overemphasized rather than the practices depending on problem solving.

27. In the training course, new learning topics were taught correlated with the previous learning's.

28. In the training course, participants were given opportunities to learn by themselves.

29. Instructors paid attention to their speech' being understood by all the participants.

30. Instructors and participants acted in unison in order to find a solution to an existing administrative problem in the training

$173 \quad 1,70 \quad 96$

9353

53,4

$57 \quad 32,8$

32,8

4,0

13

7,5

$3 \quad 1,7$

170

17

$2,48 \quad 1,04$

$174 \quad 3,79 \quad, 94$

171

$171 \quad 4,07 \quad, 85$

18,4

174

$74 \quad 2,4$

173

\begin{tabular}{|c|c|c|c|c|c|c|c|c|c|c|c|}
\hline 172 & 3,98 & 67 & 2 & 1,1 & 5 & 2,9 & 13 & 7,5 & 125 & 71,8 & 27 \\
\hline 174 & 3,60 & ,93 & 3 & 1,7 & 24 & 13,8 & 33 & 19,0 & 93 & 53,4 & 21 \\
\hline 173 & 4,25 &, 70 & 3 & 1,7 & 1 & 0,6 & 5 & 2,9 & 104 & 59,8 & 60 \\
\hline 174 & 3,93 &, 84 & 3 & 1,7 & 10 & 5,7 & 15 & 10,9 & 105 & 60,3 & 37 \\
\hline
\end{tabular}

When the answers of school managers in table 2 were utilized, the level of participation of the school managers at "agree and strongly agree" levels related to data items, stating "The content of this CPD training course taught me new topics" is $94,9 \%$ ( $\mathrm{f}=165$ ); similarly, the level of participation at "agree and strongly agree" of the data item stating "The content of this CPD training course brought me in new skills" is $90,2 \%$ ( $\mathrm{f}=157$ ), so majority of the participants express their positive opinion about CPD course and such a finding indicates that school managers think the training course have them learn new topics and skills. 
At "agree and strongly agree" participation levels, $90,2 \%$ of the participants ( $\mathrm{f}=158)$ supported the view of "The content of this CPD training course brought me in new perspective and understanding", it indicates that the training course is considered to give new perspective and understanding to the school managers.

The view of school managers related to data item "The training course that I have joined is likely to improve my professional knowledge, qualifications and skills" is rather supportive as the rate of participation at "agree and strongly agree" levels is $92 \%$ (f=158). Similarly, the "agree and strongly agree" participation levels of the other data items such as "The training course had me gain the necessary knowledge and qualifications which I can apply to my managerial life" $(86,8 \%)$, "The new knowledge and qualifications in the content of training course is applicable in management" $(91,9 \%)$ are also relatively high. It indicates that school managers believe that CPD course they joined has positive effects on improvement of their professional knowledge, qualifications and skills, moreover, these new knowledge and qualifications can be applied for their further managerial duties.

Data item of "The time was effectively used in the training course" related to time management of the CPD course was supported by participants as the rate of participation at "agree and mostly agree" levels was relatively high and positively $(84,5 \%)$. Participants think that the time in the training course was effectively used.

The data items about the instruction and instructors of the CPD course got also quite high level of participation at "agree and strongly agree" levels by the participants, the data item stating "Instructors made enough explanation about the topics" (94,2\%)" were strongly supportive as the participants displayed 93,1\% rate of participation. Likewise, the "agree and strongly agree" participation levels of the other data items, such as "Instructors had enough knowledge and skills related to content of the course (93,1\%); "Instructors gave enough samples related to topics" (90,2\%) are also relatively high. It indicates that the instructors of CPD course are thought to have enough professional knowledge, qualifications and skills, moreover, the topics are thought to explained adequately, and enough number of samples about the topics are thought to given by the instructors.

The data item stating that "Instructors paid attention to their speech' being understood by all the participants" got 94,3\% ( $\mathrm{f}=164)$ rate of participation at "agree and strongly agree" levels which indicates the CPD course is found to be clearly understood. Likewise, rate of participating of data item stating that "Instructors and participants act in unison in order to find a solution to an existing administrative problem in the training course" got also relatively high participation (81,6\%; $\mathrm{f}=142$ ), and it indicates that a learning model based problem solving and cooperative was used in CPD course.

The data items about the communication climate of the CPD course got quite high level of participation at "agree and strongly agree" levels, the data items stating "There was an effective communication environment at the course" are strongly supportive as the participant displayed $92 \%$ rate of participation. Likewise, the "agree and strongly agree" participation levels of the other data item, stating "Participants did adequately benefit from the opportunities of conversation" (90,2\%); "Instructors gave enough samples related to topics" (90,2\%) are also relatively high. It indicates that the communication climate of the CPD course is considered to be sufficient by the participants.

The data items stating "The course has clear training objectives which are observable and evaluable" and "The content of the training course is prepared accordance with the predetermined objectives" got relatively high level of participation at "agree and strongly agree" levels. Those items related to objectives dimension of CPD course were found to be sufficient by the participants since their participation rates were $81 \%$ ( $\mathrm{f}=141)$ and $78,1 \%(\mathrm{f}=136)$.

The data item stating "The training course was not forth attending, it was waste of time" is expected to have relatively high level of participation at "strongly disagree and disagree" levels since it is a negative statement item. As it was expected, the participation level of this item is relative high $(86,2 \% ; \mathrm{f}=150)$ and it indicates that the participant finds the $\mathrm{CPD}$ course sufficient and effective enough and worth attending for their managerial skills.

The data item stating "Suitable educational tools and equipment were used during the training course" (76,4\%; $\mathrm{f}=133)$ and "The new knowledge I got during the training course will increase the success at my profession" (85,7\%; $\mathrm{f}=149)$ had relatively high level of participation at "agree and strongly agree" levels. The CPD course was found to be sufficient in terms of educational tools and equipment, and to make contribution to success of their profession.

The participation levels to data item "In training courses, a knowledge learning procedure is overemphasized rather than the practices depending on problem solving" displayed incoherent, it was $32,2 \%(\mathrm{f}=57)$ both at "agree" and "disagree" levels. This indicates that school managers have different perspectives towards instruction of the CPD course, basically, it can be considered a conflict between content based instruction and problem based instruction perspectives of the school managers. However, relatively high participation levels to data item "In training courses, participants are given opportunities to learn by themselves" (65,5\%; $\mathrm{f}=114)$ indicates that school managers pay more attention to self-learning and find the CPD course sufficient enough in terms of self-learning opportunities. 
When all the data items in the survey were focused, data items stating that "Instructors had enough knowledge and skills related to content of the course" $(\mathrm{m}=4,46)$; "Instructors made enough explanation about the topics" $(\mathrm{m}=4,36)$; "Instructors gave enough samples related to topics" $(\mathrm{m}=4,36)$ and "The content of this CPD training course taught me new topics" $(\mathrm{m}=4,35)$ are found to have the highest average score among the 30 data items. This result backed up the finding of instructors of CPD course had enough professional knowledge, qualifications and skills, moreover, the topics were explained adequately, and enough number of samples about the topics were given by the instructors.

\subsection{The Findings Related to Qualitative Dimension of the Study}

The opinions of school managers related to open ended questions what made the strongest contribution in this CPD course to their professional development and what should be done for this CPD course being more efficient were explained under this heading.

3.2.1 The Finding Related to What Made the Strongest Contribution in this CPD Course to School Managers' Professional Development

The opinions of school managers on what made the strongest contribution to their professional development basically focus on the themes in table 3 . According to these findings, school managers think the topics such as school management and qualification of school managers, inspection and supervision technics, leadership, general knowledge of legislation, school counseling, knowledge of protocol and ceremony, personal development, disciplinary actions related to staff and students made the strongest contribution to their professional development during the CPD course.

Table 3. Topics regarded to make the strongest contribution to professional development in the training course

\begin{tabular}{lcc}
\hline Topics & $\mathrm{f}(\mathrm{n}=149)$ & $\%$ \\
\hline School management and qualifications of school managers & 38 & 25,5 \\
Inspection and supervision technics & 33 & 22,1 \\
Leadership & 25 & 16,7 \\
General knowledge of educational legislation & 23 & 15,4 \\
Psychological school counseling & 19 & 12,7 \\
Rules of protocol and ceremony & 17 & 11,4 \\
Personal development & 15 & 10 \\
Disciplinary actions related to staff and students & 14 & 9,4 \\
Time management & 10 & 6,7 \\
Communication skills & 10 & 6,7 \\
Rules of official correspondence & 6 & 4 \\
Fiscal laws and regulations & 6 & 4 \\
School hostels management & 4 & 2,6 \\
Professional and administrative ethics & 3 & 2 \\
Strategic planning & 3 & 2 \\
\hline
\end{tabular}

The most frequently stated topic by the participants was school management and qualifications of school managers $(25,5 \%)$. Such a result might stem from the seniority of the school managers because $66 \%$ of the participants have the seniority of 1-10 years and haven't got long experiences in school management. Additionally, 16,7\% of the participants stated that the topic of leadership, which is considered as an important part of management, made the strongest contribution to their professional development at the CPD course they participated.

Some of the opinions stated by participants are seen in following quotations.

".......... suggestions towards the solution of the problems that we might come across as a school manager" (M-8);

"Topics related to management and managerial problem solving made the greatest contribution to my professional development, the other topics also made contribution" (M-37);

"Information about school legislation, protocol rules, especially the leadership, and fiscal laws and regulations" (M-1) 
Inspection and supervision technics has also been one of the most frequently stated topics by the participants ( $22,1 \%)$. With the current regulation towards Turkish inspection system, school managers are also commissioned as investigators for educational staff disciplinary inquiries which was previously conducted by educational inspectors. For that reason, inspection and supervision technics as a new duty for school management might arouse interest of school managers.

When the topics in Table 3 are reviewed, it is seen that the school managers take the school management and legislation as a primary issue. As a result, topics such as school management and qualifications of school managers $(25,5 \%)$, inspection and supervision technics (22,1\%), leadership (16,7\%), general knowledge of educational legislation $(15,4 \%)$ were more frequently stated by the participants as topics to make contribution to professional development compared to other topics in the CPD course.

\subsubsection{The Finding Related to What should be Done for CPD Courses Being More Efficient.}

Participants' recommendations towards CPD course gather round the topics in table 4. Participant's recommendations mainly focused on the planning and timing of CPD courses. They also made suggestions about content of the training topics, duration of the courses, and facilities of the CPD courses.

Table 4. Recommendations towards CPD course's being more efficient

\begin{tabular}{lcc}
\hline & $\mathrm{f}(\mathrm{n}=149)$ & $\%$ \\
\hline Timing of the CPD courses should be scheduled in a better way & 39 & 26,2 \\
There should be more emphasis on practical knowledge towards daily administrative & 27 \\
problems of school directors & 18,1 \\
$\begin{array}{l}\text { Duration of the CPD courses should be extended and training topics should be given in } \\
\text { an extended schedule. }\end{array}$ & 22 \\
$\begin{array}{l}\text { Location and facilities of the CPD courses should be organized in a better way } \\
\text { Shuttling facilities to the course center should be better organized and participants should }\end{array}$ & 20 \\
$\begin{array}{l}\text { be financially supported for shuttling. } \\
\text { CPD courses should be organized as distant training }\end{array}$ & 18 \\
Participation to CPD courses should be based on voluntariness & 5 \\
Training topics should be supported with written material and notes & 2 \\
\hline
\end{tabular}

Participants put excessive emphasis on the timing of the CPD course and they recommended that the CPD courses should be organized in a way not to hinder the school management and education at school. School manager complained more about timing because they had to attend CPD course and they had to fulfill their managerial duties while the education at school was going on.

Some of the recommendations stated by participants are seen in following quotations.

"I think the timing of this training course was wrong, if it had been organized in semester or summer holiday, not in the busiest time of the school year, we could have conducted the works at school in a better way and not hindered" (M-6);

“...the timing of CPD course is not suitable for us, it could have been organized in a better time that would not hinder the school management” (M-16);

“...it should be organized during the school holidays when there is no education at school” (M-78);

“...the training course could have had a better timing, we had problems because of the workload piled up at school during the CPD course" (M-139).

One of the other recommendations of the school managers was that there should be more emphasis on practical knowledge towards daily administrative problems of school managing. Those school managers recommended that there should be application-oriented information at the training course rather than theoretical and academic information about management.

"Beside theoretical and academic information, practical and operative activities could be conducted" (M-49)

"It should be better to present the topics depending on half theoretical and half applicable information" (M-55) 
"It will enrich the training if presentations are supported with further visual quality and explained via concrete cases related to management” (M-75)

"If the school managers are informed about the most common problems in school management, it will be better" (M-79)

"Theoretical knowledge learned in such training courses should be able to transferred into real life cases, not just remained on papers" (M-107);

Participants also made recommendation about the facilities of the CPD course. Some of the recommendations made by participants are seen in following quotations.

“A better ground for such a course should be chosen” (M-17);

"The training ground and facilities should be better organized, participants should be informed about the topics beforehand, the location and the transportation service should be favorable for all the participants" (M-85).

"The training course should be held in summer holiday, the facilities in the training ground should be better" (M-136).

Participants also made recommendations about transportation services and shuttling facilities to the course center, CPD courses being organized as distant training, CPD courses being on a volunteer basis,

"School managers working at country side and who are supposed to join these kinds of training courses should have provisions and be financially supported" (M-1);

"First of all, participation to CPD courses should not be compulsory and be based on voluntariness. The content of the training course should be addressed to practical knowledge and daily administrative problems of school directors rather than the theoretical legal and legislative information, facilities should be better organized, as a school manager working at country side I think it is unpleasant to be obliged to attend the training course without any provisions or financial support”, (M-4);

"Those school managers attending the training from remote locations should be financially supported for travel allowance; if possible, CPD courses should be organized as distant training...” (M-7);

"I think, if we could supply the needs of transportation services and shuttling facilities for the participants, the training course would be more sufficient” (M-18);

"If the training courses could hold during the summer holidays, they wouldn't hinder the education at schools; shuttling facilities should be supplied for those colleagues coming from country side” (M-72);

"The training grounds should be comfortable, spacious and the problems with transportation services and shuttling should be solved" (M-129);

\section{Conclusions and Discussion}

CPD activities in the world are known to vary across the countries depending on socio-cultures, management styles, education levels and perspectives. Countries budgeting large amounts for education are also considerably more successful in CPD training, moreover, these countries are considered to be highly productive and efficient at personal and organizational levels (Öztürk and Sancak, 2017). In this study, it was aimed to disclose how the CPD courses have been commented by school managers and also depict the current CPD activities organized by local educational directorates towards teachers.

Depending on the finding both at quantitative and qualitative dimensions of the study, the following results were concluded:

1) The CPD course led the participants acquire new knowledge and skills, and have new perspective and understanding related to school management.

When the school managers are thought to be educational leaders of the schools, CPD activities are expected to improve their managerial skills. The quantitative findings of the study concluded that CPD training course sophisticated school directors on new knowledge and skills, this result was also supported the qualitative findings as the participants stated that topics such as school management and qualifications of school managers $(25,5 \%)$, inspection and supervision technics $(22,1 \%)$, leadership $(16,7 \%)$, general knowledge of educational legislation $(15,4 \%)$ made great contribution to their professional development. This result is consistent with the study of Kanlı and Yağbasan (2002) in which CPD courses were found to be efficient for teachers' improving their professional knowledge and skills. It has been determined that Kanlı and Yağbasan (2002) reached the conclusion that the CPD training course held is effective in improving the 
professional knowledge and skills of the teachers. In this regard, it can be said that related studies share similarity to the results obtained in this research. However, Özcan and Bakioğlu (2014) found in their studies that average level of impact on their professional development and duties on the fact that the school principals and the teachers has had CPD training is on low, according to their own perceptions; whereas it was moderate in some subjects when it is considered on thesis basis. In this study, it is seen that similar results were obtained with the thesis on literature whereas the positive professional attitude that is contributed to the teachers due to having CPD training that is contradictory to the research carried out by Özcan and Bakioğlu (2014). In addition, in the study carried out by Yalın (2005), the fact that the knowledge and skills aimed at the program in the CPD training activities are not sufficient demonstrate differences between the results of this study.

2) The content of training course and qualification of the instructors were found to be efficient by the participant school managers. In quantitative dimension of the study, it was concluded that participants were satisfied with the instructors' explanation about the topics, knowledge and skills related to content of the course, they also thought that the instructors gave enough samples related to topics and paid attention to their speech' being understood by all the participants. The content of the training was also found to be sufficient and the time was effectively used, so the training was worth attending for them, and the participants also thought that the new knowledge they got during the training course will increase the success at their profession.

When the literature considered, Gültekin and Çubukçu (2008) found that teachers having CPD training is beneficial both in institutional and individual terms; George and Lubben (2002) found that teachers who participated in CPD training programs positively contributed to their professional and social development on the related topics. In the research conducted by Okçabol, Akpınar, Caner, Ertkin, Gök and Ünlühisacikli (2003) with the teachers, the fact that the course education and the instructor is not efficient has similar results with the fact that the most useless aspect of the CPD training activities is the inadequacy of the trainers involved in this practice. However, in the study conducted by Yalın (2005), the result of "the instructors to be assigned in the CPD training activities are not selected among the people who are experts in their field" is contradictory to the fact that the instructor of this research is sufficient.

3) The CPD course was found to be sufficient in terms of educational tools and equipment. This negative case should be supported by the fact that the CPD training activities expressed by Uçar and İpek (2006) should be organized in a planned and systematic way in line with the needs, desires and expectations of principals and teachers and these activities should be carried out at appropriate times in terms of participants by encouraging the participation of principals and teachers in these activities (by way of remuneration, promotion, assignment, etc.). However, the opinion stated by Ümran and Türkoğlu (2017) that "teachers should be supported financially while attending in-service training activities and awarded at the end of the participation process" is a finding similar to this situation. In addition, the skills to be given during the CPD training should be provided by the experts in the fields of learning environment and the efficient methods-techniques and the equipment to be used (Uçar \& İpek, 2006).

4) School managers pay more attention to self-learning and find the CPD course sufficient enough in terms of self-learning opportunities. Akbas and Uzunöz (2012) have come to the fore that they have adopted the idea that teachers should practice the subjects in a way that is practical and they should also be actively involved in the research they conducted with geography teachers. In the study in which the teachers are passive recipients, the result that the CPD training should provide opportunities for self-learning is supported.

5) Participants are concerned about the teaching methodology of the training course and they demand to have teaching methods which will depend on practical and operative activities rather than theoretical and academic information. This indicates that school managers have different perspectives towards instruction of the CPD course, basically, it can be considered a conflict between content based instruction and problem based instruction perspectives of the school managers. Moreover, in qualitative dimension of the study participants recommended that there should be more emphasis on practical knowledge towards daily administrative problems of school directors and duration of the CPD courses should be extended and training topics should be given in an extended schedule.

6) The participants were not satisfied with the facilities supplied by the CPD organization. In qualitative dimension of the study, school managers brought criticism about location of the training center, shuttling and the training ground. The fact that Ayvac1, Bakırc1 and Yildiz (2014) believe that the teachers who participated in the study consider that the expenditures they spend on CPD activities "cause additional burdens for the family budgets" is similar to negative thoughts regarding the CPD training in this research. In the study conducted by Sezer (2006), it was determined that the participants found the CPD training activities inadequate in terms of the scope, the environment and the contribution of the activities on the implementation. However, Konokman, Tanriseven and Karasolak (2013) have interpreted that the teachers' attitudes towards CPD training were negative determining that the attitude scores of CPD training activities of 
the teachers were below average. It seems possible to say that the results of the relevant researches have complied with the dissatisfaction with the CPD training in this study.

7) The timing of the CPD course was not welcomed by the participants. Many participants in qualitative dimension of the study stated their negative concern about the timing of the CPD course as it was held within educational year and as they had to manage their school simultaneously. Ayvac1, Bakırc1 and Yldez (2014) support the result of the fact that there is a problem with the scheduling of CPD trainings, just as the teachers participating in the study they conducted express that they are disturbed by the fact that the CPD training activities are held in the summer months.

\section{Suggestions}

1) The result of the study indicated that CPD training have great potential to lead new perspective and skills for school directors, so the number of the CPD activities towards school managers should be increased.

2) The timing of the CPD courses towards school managers should be arranged especially during the holiday times in order not to hinder the school management.

3) The ground and location of the training course should be attentively arranged, facilities of shuttling and transfers should be supplied for the participants.

4) Participants attending the training course from remote locations should be financially supported for travel allowance.

5) Interactive internet based CPD courses should be organized as distant training.

6) Theoretical and academic based methodology of the training course should be replaced by more practical and operative activities.

\section{References}

Akbaş, Y. \& Uzunoğlu, A. (2012). Reflections of geography teachers concerning sufficiency of inservice training: Trabzon case. Journal of Black Sea Studies, 12(12), 189-202.

Atakl1, A. (1992). Education and professional achiement. Journal of Productivity, Ankara: MPM.

Ayvacı, H., Ş., Bakırcı, H. \& Yıldız, M. (2014). Science and technology teachers views and expectations about ın-service training practices. Amasya Education Journal, 3(2), 357-383.

Aytaç, T. (2017), Hizmet içi eğitim kavramı ve uygulamada karşılaşılan sorunlar. It was taken http://dhgm.meb.gov.tr/yayimlar/dergiler/milli_egitim_dergisi/147/aytac.htm.

Büyüköztürk, Ş., Akgün, E., Ö., Demirel, F., Çakmak, E. K., \& Karadeniz, Ş. (2018). Scientific research method. Ankara: Pegem A.

Creswell, J.W. (2006). Understanding Mixed Methods Research, (Chapter 1). Sage Pub.

George, J. M., \& Lubben, F. (2002). Facilitating teachers' professional growth through their involvement in creating context-based materials in science. International Journal of Educational Development,22(6), 659-672. https://doi.org/10.1016/S0738-0593(01)00033-5

Gültekin, M. \& Çubukcu, Z., (2008). Perceptions of primary school teachers about in-service training. Journal of Social Sciences, (19), 185-201.

Karaman, Ü. (1983). Müfettiş Yeterliklerinin Saptanması ve Hizmetiçi Eğitim Programı Hazırlanması A.Ü.- Eğitim Bilimleri Fakültesi Dergisi, Ankara: Sevinç Matbaası.

Karasar, N. (2017). Scientific research method. Ankara: Nobel Publication.

Konokman, G. Y., Tanrıseven, I., \& Karasolak, K. (2013). Examining prospective teachers' attitudes towards educational research according to several variables. KEFAD, 14(1), 141-158.

Kulaz, E. (2013) İlkokul öğretmenlerinin kendilerine yönelik hizmet içi eğitim uygulamalarının koşullarl ve verimliliği hakknndaki görüşleri. Yüksek Lisans Tezi, Yeditepe Üniversitesi, Sosyal Bilimler Enstitüsü, İstanbul.

Johnson, B., \& Turner, L. A. (2003). Data collection strategies in mixed methods research. In A. Tashakkori \& C. Teddlie (Eds.), Handbook of mixed methods in social and behavioral research (s. 297-319). Thousand Oaks, CA: Sage Publications Inc.

Okçabol, R., Akpınar, Y., Caner, A., Erktin, E., Gök, F. \& Ünlühisarcıklı, Ö. (2003). Research of teacher training. Ankara: Eğitim-Sen. 
Özcan, Ş. \& Bakioğlu, A. (2010). A meta-analytıc effect analysis: The effect of in-service training on the job performance of school administrators. H. U. Journal of Education, 2010(38), 201-212.

Öztürk, D. \& Sancak, S. (2007). The effect of in-service training practices on working life. Journal of Yaşar Unversity, 2(7), 761-794.

Pehlivan İ. (1997). Research on in-service training problems in Turkish publich sector. Journal of Productivity, 97(3), 131.

Punch, K. F. (2005). Introduction to Social Research-Quantitative \& Qualitative Approaches. London: Sage Publications Inc.

Sabuncuoğlu, Z. (2005). Human resources management. Bursa: Alfa Aktüel Publication.

Sezer, E. (2006). Ministry of education, state schools guidance couselors and psychological consultants views regarding in-service training (The case of İstanbul). Unpublished master's thesis. Yeditepe University, İstanbul.

Taymaz, H. (1997). In-services training concepts principles methods. Ankara: Takav Pub.

Taymaz H., Sunay Y. \& Aytaç T. (1997). Coordination meeting in in-service training. Journal of National Education, 133, 14-15.

Uçar, R. \& İpek, C. (2006). The vıews of primary schools administrators and teachers about in-servıce training programs in the Turkish educational system. YYU Journal Of Education Faculty, 3(1), 34-53.

Ümran, Ş. \& Türkoğlu, A. (2017). Inservice training model suggestion for classroom teachers. Mustafa Kemal University Journal of Social Sciences Institute, 14(37), 90-104.

Yalın, H. İ., (2005). Evaluation of in-service training program. It was taken from http: llyayim. meb. gov. tr/yayinlar/150/yalin.htm.

Yıldırım A. \& Şimşek, M. (2016). Qualitative research methods in the social sciences. Ankara: Seçkin Publication. 